\title{
7. EARLY EVOLUTION OF THE SOUTH ATLANTIC OCEAN: ROLE OF THE RIFTING EPISODE ${ }^{1}$
}

\author{
Jean-Claude Sibuet, ${ }^{2}$ William W. Hay, ${ }^{3}$ Annick Prunier, ${ }^{4}$ Lucien Montadert, ${ }^{5}$ Karl Hinz, ${ }^{6}$ and Jurgen Fritsch ${ }^{6}$
}

\begin{abstract}
For the South Atlantic Ocean, the rifting period began during the Oxfordian-Kimmeridgian and ended progressively from the Hauterivian near the Agulhas Plateau to the early Albian in the vicinity of the Niger Delta. The Walvis Ridge/Rio Grande Rise system acted as a dam to marine incursions into the Angolan and Brazilian basins until the midAptian. The Parana Basin and the Torres syncline (Brazil), the Eastern Walvis Ridge and the Kaokoveld region (Namibia) form an originally continuous volcanic terrane created in the continental domain during the Late Jurassic-Early Cretaceous by tensional processes. This terrane corresponds to a failed rift arm extending into South America and involving about $100 \mathrm{~km}$ of extension in the Late Jurassic to Early Cretaceous. These factors provide new constraints for the early kinematic evolution of the South Atlantic.
\end{abstract}

\section{INTRODUCTION}

This synthesis chapter relates results of Leg 75 drilling in the Angola Basin (Site 530) and on the Walvis Ridge (Sites 531 and 532) (Hay, Sibuet et al., 1982) to the framework of the early evolution of the South Atlantic Ocean and formation and evolution of the Walvis Ridge.

It is only during the past decade that we have obtained detailed knowledge of the structure of the Walvis Ridge (e.g., Barnaby, 1974; Goslin et al., 1974; Goslin and Sibuet, 1975; Bolli, Ryan et al., 1978), and the adjacent continental margins and deep basins to the south (e.g., Simpson, 1971; Rabinowitz, 1976; Scrutton, 1976; Emery et al., 1975a) and to the north of the ridge (e.g., Rabinowitz, 1972; Lehner and De Ruiter, 1977; Emery et al., 1975b; Leyden et al., 1972), and are able to place these features into the context of models of the evolution of the South Atlantic (Ladd et al., 1973; Francheteau and LePichon, 1972; Sibuet and Mascle, 1978; Rabinowitz and LaBrecque, 1979; van Andel et al., 1977; LePichon et al., 1978; Bolli, Ryan et al., 1978).

Additional unpublished geological data in the files of oil companies and institutions which have carried out multichannel seismic surveys in this region were made available for this study, and provide new constraints for these published models. Recent advances in understanding the development and evolution of Atlantic type (tensional) continental margins (e.g., Montadert et al., 1979a; Royden et al, 1980; LePichon and Sibuet, 1981) also contribute to our understanding of the early evolution of the South Atlantic. The above studies and the results from Deep Sea Drilling Project (DSDP) Leg 75

\footnotetext{
${ }^{1}$ Hay, William W., and Sibuet, Jean-Claude, et al., Init. Repts. DSDP, 75: Washington (U.S. Govt. Printing Office).

2 Centre Océanologique de Bretagne, B. P. 337, 29273 Brest Cedex, France.

3 Museum, University of Colorado, Boulder, Colorado 80309.

4 Société Nationale Elf-Aquitaine (Production), Tour Générale, La Defénse 9, 92088 Puteaux, France.

5 Institut Français du Pétrole, 1-4, avenue de Bois-Préau, 92506 Rueil-Malmaison Cedex, France.

6 Bundesanstalt für Geowissenschaften und Rohstoffe, Stilleweg 2, Postfach 5101 53, D3000 Hannover 51, Federal Republic of Germany.
}

enable us to modify and improve previous ideas and hypotheses concerning the initiation and early evolution of the South Atlantic.

\section{Origin of Data}

The continental margin off South Africa and Namibia south of Cape Frio $\left(18^{\circ} \mathrm{S}\right)$ has been investigated by the Southern Oil Exploration Corporation (SOEKOR) (Gerrard and Smith, 1983). This study provides a regional interpretation based on $30,000 \mathrm{~km}$ of commercial seismic profiles and ten wells drilled on the continental shelf south of the Orange River between $28^{\circ} \mathrm{S}$ and $33^{\circ} \mathrm{S}$.

The tectonic and stratigraphic evolution of the continental margin off Angola and Gabon has been interpreted by geologists of the Gulf Oil Exploration and Production Company from studies of onshore and offshore Cabinda, based on geophysics and data collected from several hundred wells over the past 20 years (Brice et al., 1983). This area occupies a median position along the African continental margin from Angola to Gabon, and is regionally significant. DSDP Holes 364 and 365 provide additional information.

Three multichannel surveys have been conducted in the area of the eastern Walvis Ridge and adjacent Cape and Angola basins (Fig. 1): (1) jointly by the Centre National pour l'Exploitation des Océans (CNEXO) and the Institut Français du Pétrole (IFP) in 1977; (2) by the Bundesanstalt für Geowissenschaften und Rohstoffe (BGR) in 1978; and (3) by the University of Texas in 1979. DSDP holes at Sites 362, 363, 530, 531, and 532 (Fig. 2) permit calibration of the seismic data (Sibuet et al., this volume).

\section{Definition of Tectonostratigraphic Units}

Tectonostratigraphic units defined on the basis of seismic data and DSDP holes drilled on passive continental margins (e.g., Montadert, Roberts et al., 1979b; de Graciansky, Poag et al., in press) have been related to three main stages of evolution of continental margins:

1) The prerift sequence corresponds to continental basement, but may include volcanics and a sedimentary 


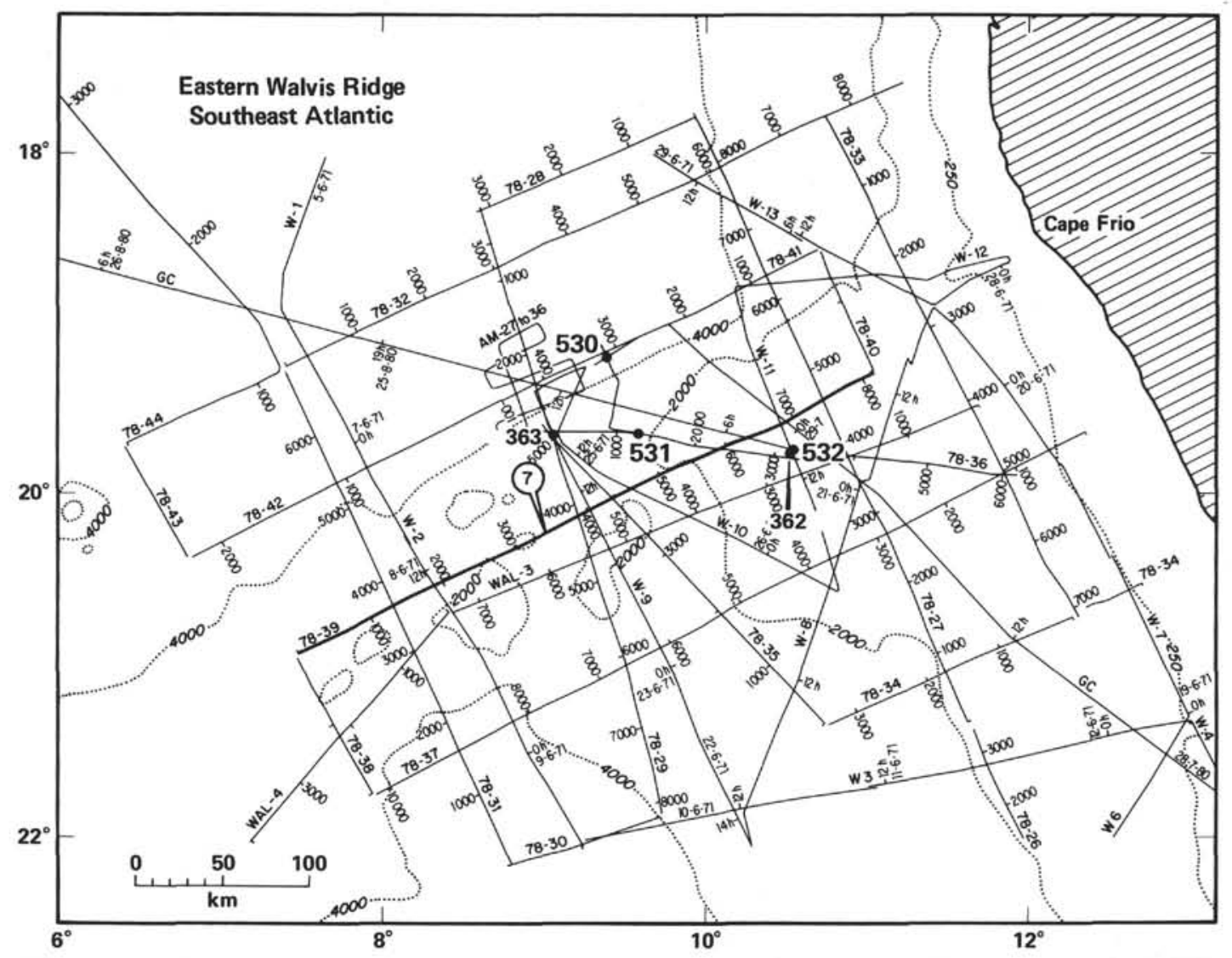

Figure 1. Location of seismic lines in the eastern Walvis Ridge area by CNEXO, IFP, BGR, and UTIG, plus DSDP sites. Simplified bathymetry in $\mathrm{m}$.

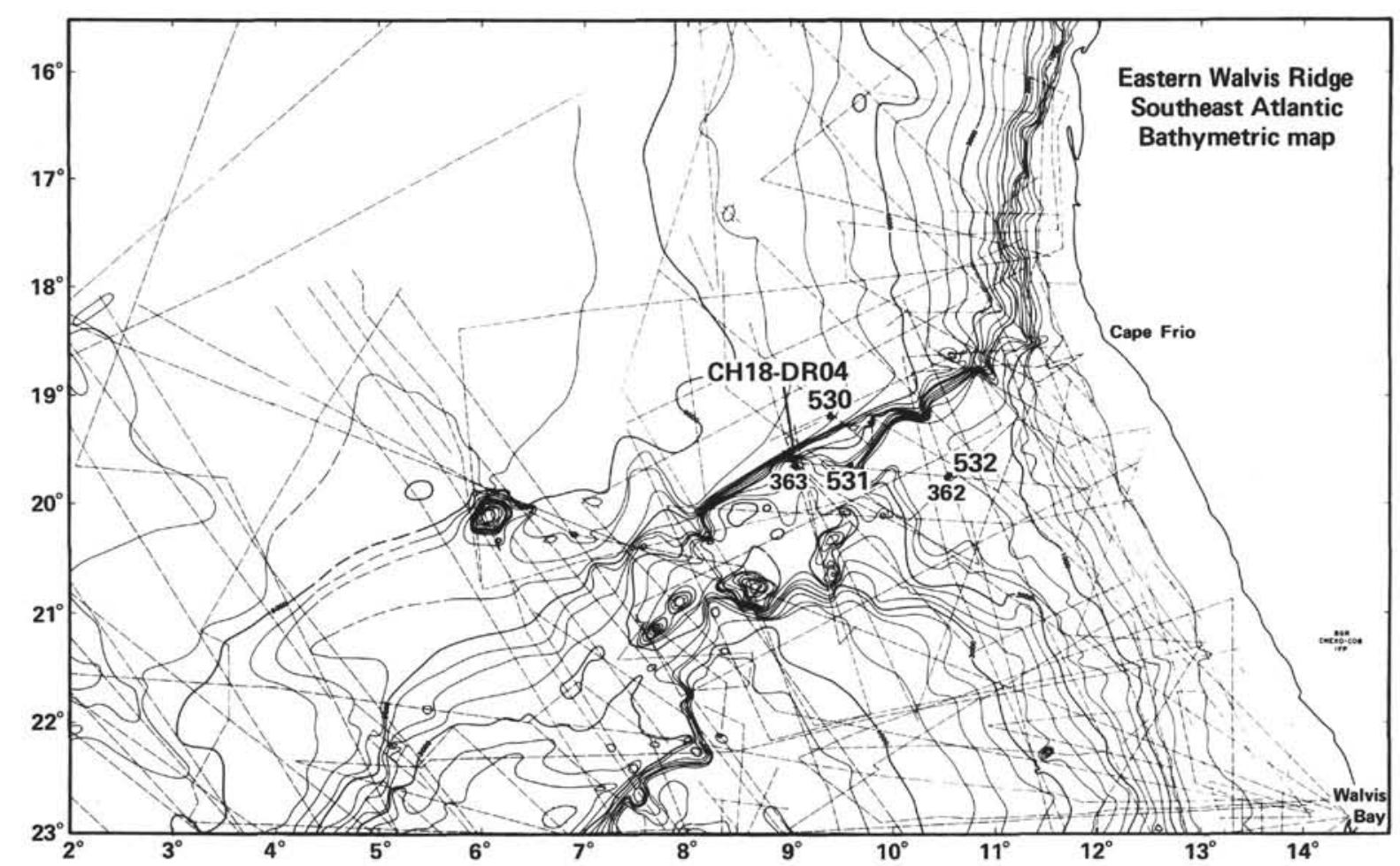

Figure 2. Bathymetric map of the eastern Walvis Ridge in Mercator projection; trackline control in dashed lines. Depths are in corrected $\mathrm{m}$ (Matthews, 1939). Contour interval is $250 \mathrm{~m}$. Position of DSDP sites is shown. 
sequence deposited before the tensional movements which resulted in the formation of the continental margin. The sediments may be deposited in depressions created in an early stage of development, as is the case for the Bay of Biscay where there was a tensional episode during the Permian-Liassic at the site of the future break-up of continents before a major episode of rifting during the Late Jurassic to Early Cretaceous (Foucher et al., 1982), or, as was apparently the case for a shorter period during the early late Triassic on the site of the central North Atlantic (Hay et al., 1982), preceding the late Triassic-Liassic faulting phase.

2) The synrift sequence, associated with strong tectonics, corresponds to the rifting phase. The duration of the rifting phase is typically 20 to $40 \mathrm{~m}$.y. and the expansion rate is about $0.2-0.5 \mathrm{~cm} / \mathrm{yr}$., an order of magnitude lower than normal seafloor spreading rates. During this tensional phase the continental crust is thinned. If sedimentary cover exists, typical tilted fault blocks appear; their angle of tilting may reach 20 to 30 degrees for values of stretching of the continental crust greater than a factor of 2 (LePichon and Sibuet, 1981). The tilted fault blocks form an imbricate structural complex and the tilting of blocks increases with time, resulting in onlapping fan deposits in the half grabens or occurrence of volcanics hiding the prerift sequence. If prerift sedimentary cover was absent, the basement structure after the rifting episode appears chaotic. In either case, the synrift sequence is associated with strong tectonic movements.

3) The postrift sequence starts at the end of the rifting phase, when oceanic crust is emplaced. From this time onward, the subsidence of the continental margin is thermally controlled and corresponds to tilting of about one degree around the initial hinge line. The tectonic movements affecting the continental margin change completely with the beginning of the drifting stage and become moderate to weak.

The relation between tectonics and the deposition of sediments during these three main stages of passive margin development can be modified by local deformation or by movements associated with the major changes in plate motions such as those described for the South Atlantic Ocean by Sibuet and Mascle (1978).

\section{PRERIFT SEQUENCE}

The prerift sequence on the shelf south of Walvis Ridge is regarded as basement on seismic profiles. Three wells have penetrated basement below the Cretaceous sediments. At well A-A1 (Fig. 3) the basement consists of phyllites assigned to the metamorphic complex of the Pan African belt (550 m.y.). These are likely to be present over the greater part of the continental margin. Acid lavas recovered at wells A-C1 and A-C2, $20 \mathrm{~km}$ away and east of the limit of synrift deposits (Fig. 3), could be related either to outcrops of $550 \mathrm{~m}$.y. old porphyries at Saldanha Bay, $120 \mathrm{~km}$ to the southeast, or to the Jurassic acid igneous rocks known from the South American conjugate margin.

During the rifting episode, this basement was affected by tensional forces which resulted in the formation of grabens and half grabens. South of the Orange River,

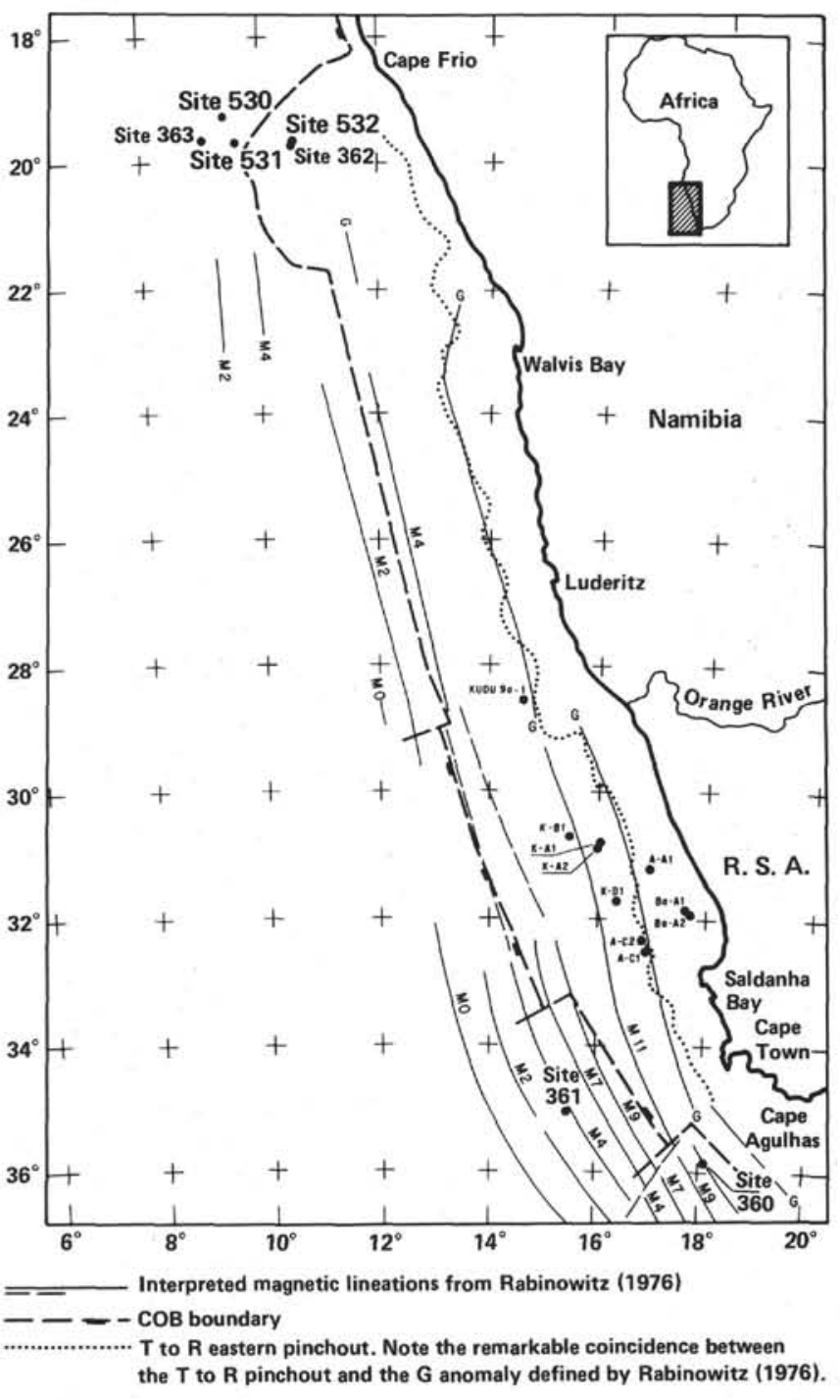

Figure 3. Major features of the eastern Walvis Ridge and of the southwestern African continental margin, adapted from Gerrard and Smith (1983) and Sibuet et al. (this volume).

these depressions are parallel or subparallel to the coast and are located about $40 \mathrm{~km}$ offshore; they vary in width from 2 to $35 \mathrm{~km}$. This system of depressions is bordered on the east by a wedge of synrift deposits and on the west by the continent/ocean boundary (COB), marked by an abrupt change from the rifting sequence to oceanic basement and sediments. Basement reflections (reflector T on Fig. 4) may disappear below the thick sedimentary sequence. This means that although no obvious dipping reflectors can be seen within the basement on the seismic section, pre-existing sedimentary or volcanic sequences are not necessarily absent all along the margin.

In the Cabinda area, the prerift fluvio-lacustrine strata underwent extensive block faulting and erosion which gave rise to steeply dipping fault blocks; measured dips exceed 20 degrees and are bounded above by a major unconformity (Fig. 5A). Up to $1,000 \mathrm{~m}$ of massive, wellsorted sands and siltstones have been drilled. These beds were deposited in and around a broad, shallow lake system in a gently subsiding intracratonic basin. The reflec- 

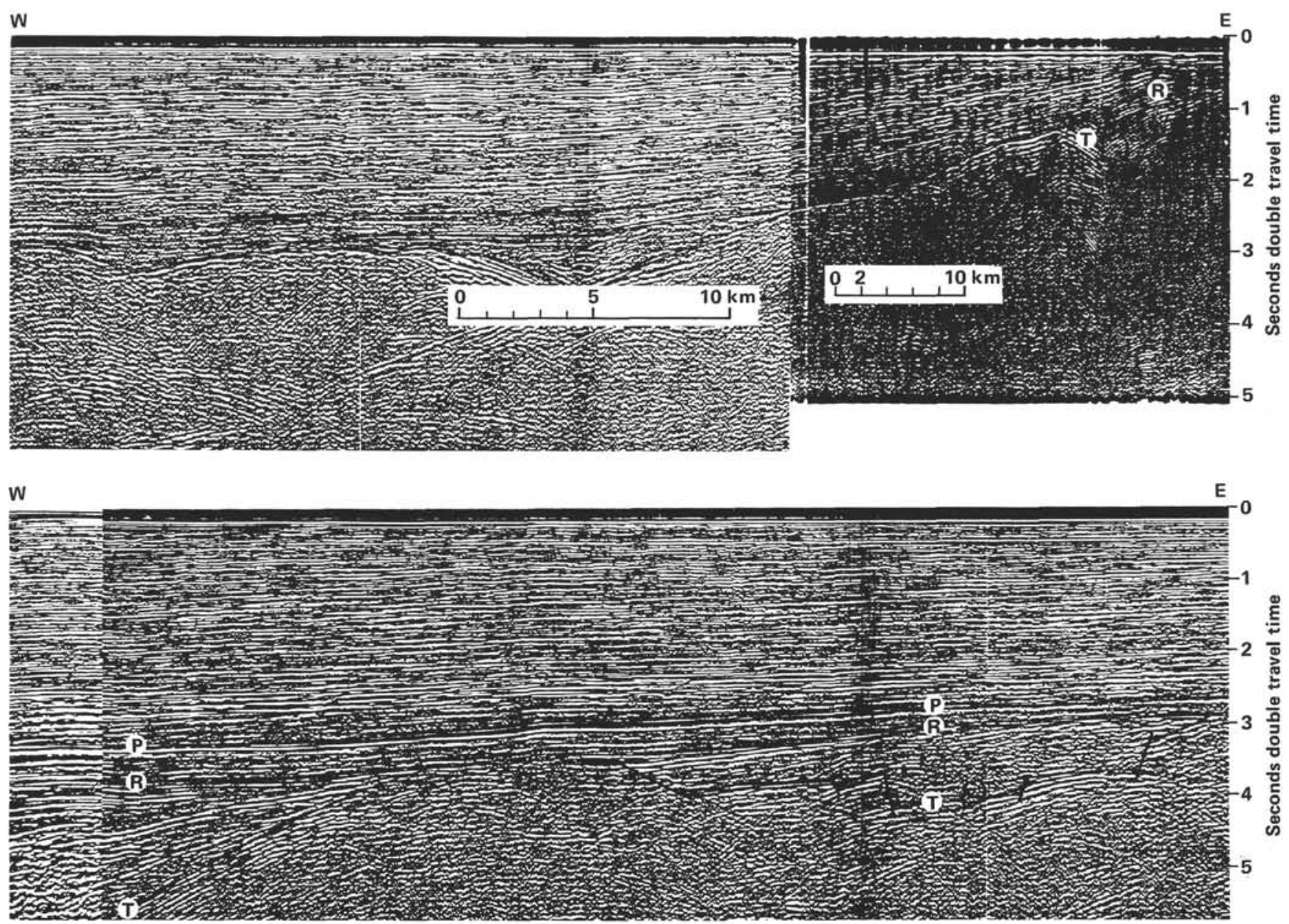

Figure 4. Portion of a composite seismic profile on the South African continental margin from Gerrard and Smith (1983). The T to R acoustic unit has been interpreted by Gerrard and Smith as the synrift sequence. Note the presence of divergent reflectors in the synrift sequence of the lower portion of the profile.

tions have an average dip of 20 degrees and show that, in the framework of the stretching hypothesis, the crustal stretching factor is of the order of 1.3 to $1.8 \mathrm{LePi}$ chon and Sibuet, 1981). Volcanics up to $30 \mathrm{~m}$ thick are often encountered at the top of the prerift sequence and have been dated as $140 \pm 5$ m.y. (Oxfordian-Kimmeridgian using the Odin time scale, 1982). These volcanics probably mark the beginning of the tensional phase which corresponds to the synrift sequence.

A prerift sequence characteristic of an intracratonic basin stage may be present around the margins of the South Atlantic Ocean, but there are only a few local onshore indications of such deposits. Permo-Carboniferous Karoo clastics have been drilled in South Africa, suggesting that downfaulted remnants of Karoo sediments may also be present offshore (Gerrard and Smith, 1983). Fluvio-lacustrine clastics were deposited in a subsiding intracratonic basin offshore of Cabinda (Brice et al., in press.) Triassic and Jurassic sediments were deposited in coastal basins along the Brazilian margin between $10^{\circ} \mathrm{S}$ and $20^{\circ} \mathrm{S}$ in the Sergipe/Alagoas, Cumuruxatiba, Camanu, and Almada basins (Asmus and Guazelli, 1981), and in the Reconcavo Basin (Asmus and Ponte,
1973). A tensional phase of possibly Permian to Triassic age occurred at the site of the future breakup of continents. Later sediments deposited in these depressions were affected by the Late Jurassic-Early Cretaceous tensional rifting phase. A few indications of a tensional regime also exist in the intracratonic Parana Basin, located west of Santos, where alkalic rocks have been dated 238 and 254(?) m.y. (Permian to Triassic; Herz, 1977).

\section{SYNRIFT SEQUENCE}

\section{South African Margin}

On the South African continental margin, the base of the synrift sequence is limited by horizon T, the rift onset unconformity, and the top is defined by horizon $\mathrm{R}$, the drift onset unconformity (Fig. 4). Gerrard and Smith (1983) propose that the western T-to-R pinchout corresponds to the $\mathrm{COB}$ marked either by the appearance of seismic reflections typical of rough oceanic crust or by a fault boundary between the two types of crust. Eastwards, the pinchout of the T-to-R wedge is associated with the limit of deposition in half grabens. 

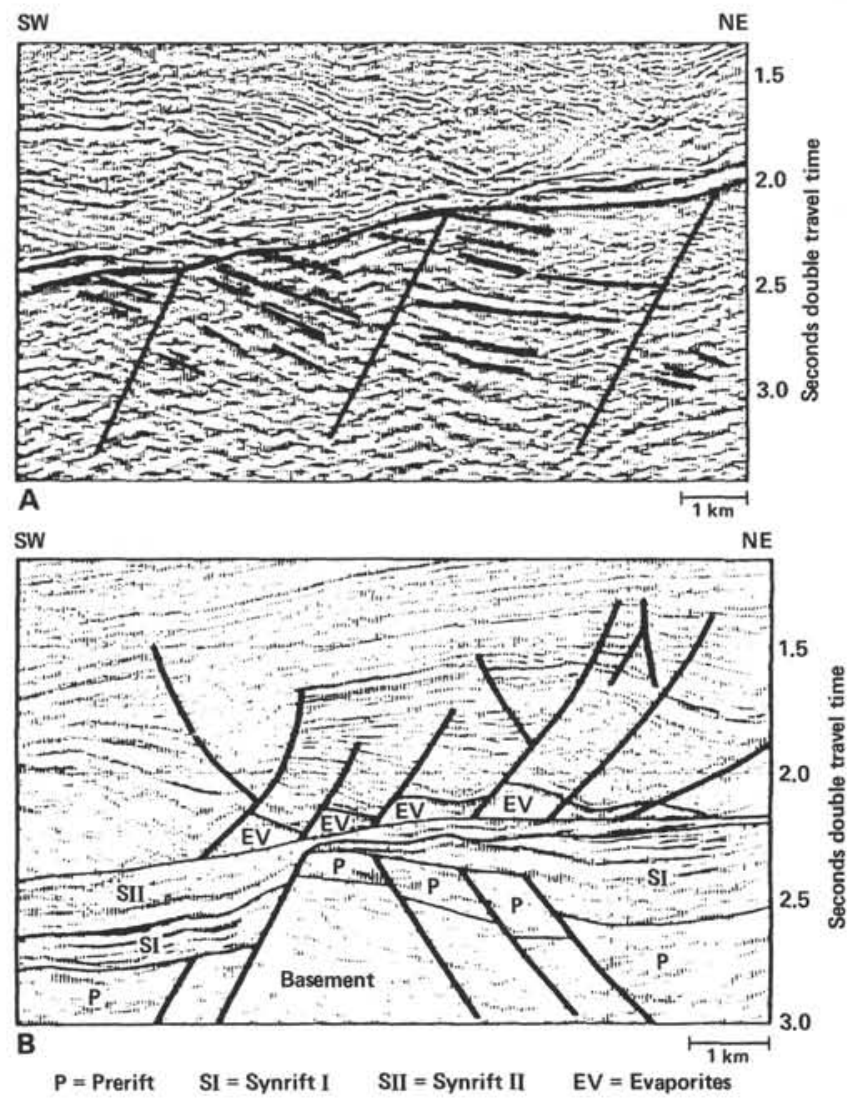

Figure 5. Seismic sections near Cabinda (Brice et al., 1983). A. Detail of a typical prerift sequence. B. The Synrift I and II sequences below the evaporites and the postrift sequence.

The pinchout line, the coastline, and the rift-valley trends are parallel except in a few areas where ancient lines of weakness were reactivated (Figs. 3, 4). Within the T-to-R unit, the presence of seismic reflectors having a slope intermediate between those of $\mathrm{T}$ and $\mathrm{R}$ records episodes of tectonic activity during the tilting of blocks (Fig. 4).

Basic lavas $690 \mathrm{~m}$ thick and a few alkaline lavas belonging to the T-to- $\mathrm{R}$ sequence have been penetrated by drilling (well A-C1) and are tentatively regarded as Middle to Late Jurassic (Gerrard and Smith, 1983). Some of the intervals within the sequence may consist of conglomerates and sandstones. It is expected that the T-to-R wedge would give rise to a linear magnetic anomaly parallel to the coast as a result of the susceptibility contrast with eastern lithologies. A gravity anomaly is also to be expected, because the density of the lavas varies from 2.53 to $2.89 \mathrm{~g} / \mathrm{cm}^{3}$. (Gerrard and Smith, 1983). The trend of the T-to-R pinchout and that of the G anomaly (Fig. 3) mapped by Rabinowitz (1976) coincide. In the area of the A-C wells this corresponds to a negative magnetic anomaly and to positive free-air and isostatic anomalies. It is apparent that in this case, the $\mathrm{G}$ anomaly does not correspond to the COB as postulated by Rabinowitz and LaBrecque (1979), but rather to the eastward limit of the thinned continental crust. Austin and Uchupi (1982) also interpreted the basement reflections west of anomaly $\mathrm{G}$ as a rifted continental crust, supporting the Gerrard and Smith interpretation. These observations have major implications for the validity of models of the initial reassembly of continents based on the fit of $\mathrm{G}$ anomalies and will be discussed further.

One characteristic of horizon $\mathrm{R}$, the drift onset unconformity, is that in some places this horizon truncates the underlying $\mathrm{T}$ to $\mathrm{R}$ sequence, as for example in the Orange and Lüderitz basins, or is truncated by a more recent unconformity of mid-Aptian age. The age of the end of deposition of the T-to-R sequence in wells has been dated biostratigraphically as Barremian or older to early Aptian.

Gerrard and Smith (1983) proposed another method to date the end of the rifting phase, based on the age of the oceanic crust at the contact of the $\mathrm{COB}$ as determined by identification of oceanic magnetic lineations. This method was previously used by Ryan (in Bolli, Ryan et al., 1978) to date the age of the salt deposition in the Angola Basin, assuming limited flowage of the salt onto the oceanic crust. The $\mathrm{COB}$ is defined by a change from a rough oceanic reflection pattern to the smoother reflection of horizon $\mathrm{R}$ of the thinned continental crust. Beneath horizon $\mathrm{R}$, dipping reflections indicate the presence of a structured internal sequence (Fig. 3) interpreted by Austin and Uchupi (1982) as subsided continental crust rather than as the top of thickened oceanic crust (Rabinowitz and LaBrecque, 1979) or feeder dike complexes and extrusives (Mutter et al., 1982). The oceanic magnetic anomalies defined by Rabinowitz (1976) abut the COB: Anomaly M11 is at $35^{\circ} \mathrm{S}$, and $\mathrm{M} 9$ at $33^{\circ} \mathrm{S}, \mathrm{M} 4$ at $30^{\circ} \mathrm{S}$ (Fig. 3); this clearly shows that the end of the rifting period is younger to the north. The ages are Hauterivian at $35^{\circ} \mathrm{S}$ and Barremian at $30^{\circ} \mathrm{S}$ according to the revised calibration of the Keatley sequence of Vogt and Einwich (1979) to the new stratigraphic time scale of Odin (1982).

These ages lie within the range of ages based on biostratigraphic determination of the $\mathrm{T}-\mathrm{R}$ sequence.

\section{Cabinda Margin}

On the Cabinda continental margin at about $5^{\circ} \mathrm{S}$, the Synrift sequence has been divided in two subunits, the Synrift I and Synrift II sequences. The younger subunit contains the change from nonmarine to marine conditions (Brice et al., 1983). The active rifting phase, which continued through the whole period, began with an active phase of uplift and block faulting of the basement. The tilted fault blocks formed a rapidly subsiding graben system $80 \mathrm{~km}$ wide in which shaly, lacustrine sediments rich in organic matter accumulated, and which extends to northern Gabon. The seismic character of the Synrift I sequence, dated as Barremian and older, is generally different from that of the prerift sequence (Fig. 5A, B).

The Synrift II sequence is marked by major basement movements with reactivation of earlier zones of faulting (Brice et al., 1983). It consists of lacustrine carbonates, sands, and clastics which grade into an evaporite sequence ranging in age from Barremian to Aptian. Brice et al. (1983) propose that the synrift period ended with an increase of subsidence at the beginning of the Albian 
after deposition of the salt. On the Gabon continental margin, the end of the synrift phase could be mid-Aptian, before the episode of salt deposition (P. Valery, pers. comm.). Because the halokinetic structures are caused both by ductile flow and brittle fracture, and because salt deposition may have occurred in a very short period (a maximum of a few m.y.), the end of the Synrift II period could be mid-Aptian or early Albian throughout the area. The nature of the crust below the salt deposits at the foot of the continental margin cannot be established because of the lack of clear oceanic or continental basement reflections. In contrast to the South African margin, no volcanic rocks belonging to the synrift sequence have been reported from the numerous Gulf Oil Company wells in Cabinda.

\section{Eastern Walvis Ridge and Kaokoveld Region}

Sibuet et al. (this volume) discuss the origin of the deep oceanwards dipping reflectors of the Eastern Walvis Ridge area previously mentioned by Hinz (1981) and Lehner and De Ruiter (1977). They propose that these reflectors might represent a thick sequence of interbedded volcanics and thin sedimentary layers. The volcanics may be related to the plateau basalts of the Kaokoveld region, which crop out on the coast at about $20^{\circ} \mathrm{S}$ and cover an area of about $10,000 \mathrm{~km}^{2}$ (Siedner and Miller, 1968; Martin, 1973). A detailed analysis of the Etendaka Plateau shows the presence of 18 horizontal flows (Siedner and Miller, 1968) about $800 \mathrm{~m}$ thick, ranging in age from 120-130 m.y., overlying sedimentary strata. Thus, it seems reasonable to suggest that the acoustic basement of structural provinces 1 and 2 (Fig. 6) of the eastern Walvis Ridge (Sibuet et al., this volume) may consist of basaltic flows which spread westwards several tens of kilometers on slopes of not more than 1 to 1,000 (Davis, 1982). Moreover, the occurrence of these onshore basalts would be concomitant with those of the synrift basalts drilled in the A-C wells on the South African margin. We suggest that basaltic flows could have been emplaced in structural provinces 1 and 2 of the eastern Walvis-Ridge at the beginning of the synrift sequence, during the Late Jurassic to Early Cretaceous (120-130 m.y. ago), in a submarine or subaerial environment (Roberts, Schnitker et al., 1982) and that the present-day deep reflection pattern is a result of tensional processes at the end of the rifting period. Dur-

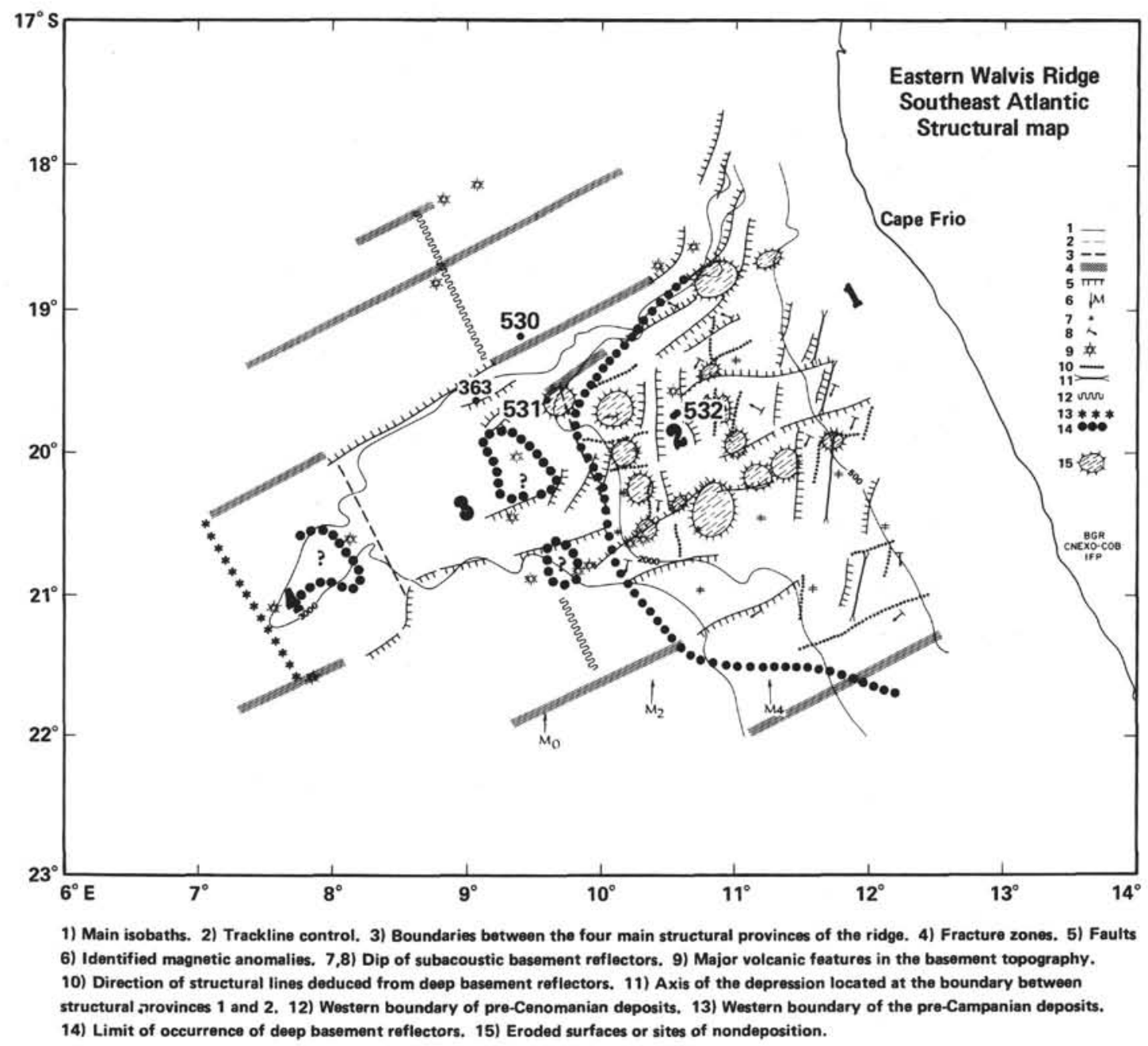

Figure 6. Structural map of the eastern Walvis Ridge. 
ing this period, an aborted rift oriented $350^{\circ} \mathrm{N}$ (Sibuet et al., this volume) was created at the boundary between provinces 1 and 2 and filled with sediments. Unfortunately, there are no drill holes on the eastern Walvis Ridge to provide direct information on the nature of the synrift sequence.

Based on seismic data, the western limit of the thinned continental crust is at the boundary between structural provinces 2 and 3 (Fig. 6). This boundary is conspicuous on the magnetic and gravity anomaly maps (Sibuet et al., this volume) because two thick crusts of different composition are juxtaposed. Goslin and Sibuet (1975), Detrick and Watts (1979), and Kogan (1979) have demonstrated that the eastern Walvis Ridge is in local isostatic equilibrium. A gravity profile, run along the axis of the eastern Walvis Ridge, from the boundary of provinces 1 and 2 to province 4 , has been compared with a two-dimensional Airy type model in which the depth of compensation is assumed to be at $30 \mathrm{~km}$. Because there is a major velocity contrast across the Oligocene hiatus between acoustic Units 2 and 3 (Sibuet et al., this volume), a two-layer density model has been adopted for the sedimentary cover (Fig. 7).

In order to determine the cause of the gravity anomaly at the limit between provinces 2 and 3 , three types of model have been tested. The first two models assume uniform crustal densities of 2.84 and $2.95 \mathrm{~g} / \mathrm{cm}^{3}$, corresponding to continental and oceanic crust, respectively. For the third model, structural provinces 1 and 2 are assumed to be of continental origin and structural provinces 3 and 4 of oceanic origin (Fig. 7). For the three models, the residual anomaly is the same $( \pm 10 \mathrm{mgal})$. The isostatic compensation is provided by a root about
$20 \mathrm{~km}$ thick below the ridge as shown by Goslin and $\mathrm{Si}-$ buet (1975); the root is of constant thickness on each side of the boundary between provinces 2 and 3 . Examining these models it becomes apparent that: (1) if the ridge has a homogeneous composition, the thickness of the crust varies by $4-5 \mathrm{~km}$ across the boundary, the thicker crust being to the east; (2) if a normal continental-oceanic density contrast is assumed, the thickness of the crust varies by $3-4 \mathrm{~km}$ across the boundary, but the thicker crust is to the west; (3) if we assume that there is no thickness variation on each side of the limit, then there is an anomalous density contrast. It is apparent that a major gravity boundary exists between provinces 2 and 3.

\section{South American Margin}

On the South American side, the rifting episode is evident from the Guyana shield to the southern extremity of the cratonic platform of Argentina (Almeida, 1972) and the Scotia arc (Dalziel and Elliot, 1972). During this episode, which began in the Late Jurassic and ended in the Aptian/Albian on the Brazilian margin, large Precambrian faults were reactivated and new faults appeared. A series of sedimentary basins were created by block faulting all along the continental margin; the most important basins on the eastern Brazilian continental margin are, from north to south: the Sergipe/ Alagoas, Reconcavo, Camamu, Almada, Cumuruxatiba/Jequitinhonha, Espírito Santo, Campos, Santos, and Pelotas basins. Several types of tensional features related to the rifting episode also are related to the earlier geology (Asmus and Guazelli, 1981). Volcanic arch features dominated the areas where subcrustal thermal

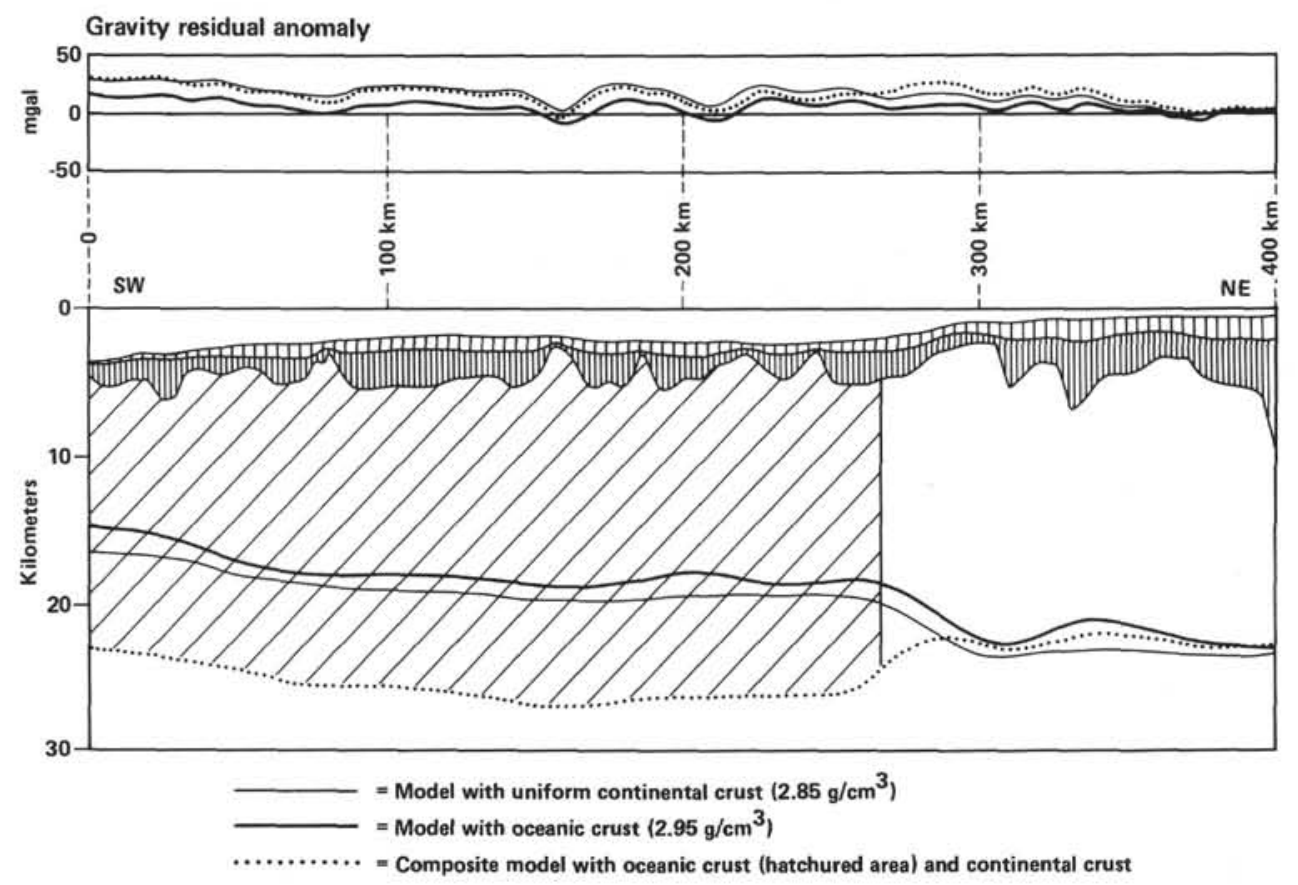

Figure 7. Two-dimensional gravimetric model in local isostatic equilibrium along the longitudinal axis of the eastern Walvis Ridge. (See location in Fig. 1.) 
processes had occurred earlier, as in the Santos Basin. Tensional crack features are represented by major antithetic faults on one side of the depression in areas of great crustal thickness or by major faulting on both sides of the depression where subsided tilted fault blocks are present (Asmus and Guazelli, 1981). Synrift sediments in shelf basins typically are composed of a thick sequence of terrigenous clastics with some interfingering volcanic rocks (Guazelli and de Carvalho, 1981) deposited before the Aptian evaporites.

There are many basins on the continental shelf and margin of Argentina south of the Rio Grande Rise. Like most of the Brazilian basins, they are normal to the coastline. South of Buenos Aires, the Rio Salado and Colorado basins are prominent. They were created and filled with sediments during the Early Cretaceous (Zambrano and Urien, 1970). Farther south, the Magellanes Basin in Patagonia also contains Upper Jurassic-Lower Cretaceous marine sediments (Dalziel and Elliot, 1972).

\section{The Paraná Basin and Torres Syncline}

The Paraná basalts, in southern Brazil, Paraguay, and northern Argentina represent the largest volume of tholeiitic flood basalt on Earth. Its surface is $1,200,000$ $\mathrm{km}^{2}$ and its volume probably larger than $500,000 \mathrm{~km}^{3}$. In the central part of the Paraná Basin 1,529 m of basalt have been drilled (Leyden et al., 1971). Normal faulting affects Lower Cretaceous sedimentary rocks of the basin. $\mathrm{K}-\mathrm{Ar}$ dating of the basalt flows and diabase dikes ranges from 110 to $148 \mathrm{~m}$.y. with a maximum of activity about 120-130 m.y. (Cordani and Vandoros, 1967; Sartori et al., 1975; Amaral et al., 1966). In the southern part of the Paraná Basin, Sartori et al. (1975) have shown that sandstone layers are interbedded with the lava flows. Mafic and ultramafic dike rocks also occur east of the Paraná Basin in the Ubatuba region, about $200 \mathrm{~km}$ southwest of Rio de Janeiro. K-Ar ages of the dikes are 125-138 m.y. (Damasceno, 1966).

Alkalic rocks have been recovered all around the Paraná Basin, and this alkalic province of southern Brazil is one of the classical petrological areas of the world. Herz (1977) and Asmus and Guazelli (1981) have compiled the data on these rocks. Emplacement of the alkalic rocks was synchronous with the Paraná basalts. The oldest dates from the alkalic province are 142 to 159 m.y., but are suspect because biotites from the same rocks give younger dates of 127-130 m.y. Major alkalic activity at the Jacupiranga and Anitapolis nodes in southern Brazil was associated with continuing uplift and fracturing between 122 and 138 m.y. As the alkalic volcanism waned, basalt flooding reached its peak in São Paulo 120 m.y. ago and in Santa Catarina 119 m.y. ago (Herz, 1977).

The Paraná Basin joins the coastline at the Torres syncline (Fig. 8), located between the two flanking arches of Ponta Grossa and Rio Grande. The Torres syncline corresponds to the only breach in the coastal belt of Precambrian basement complex between the Rio de la

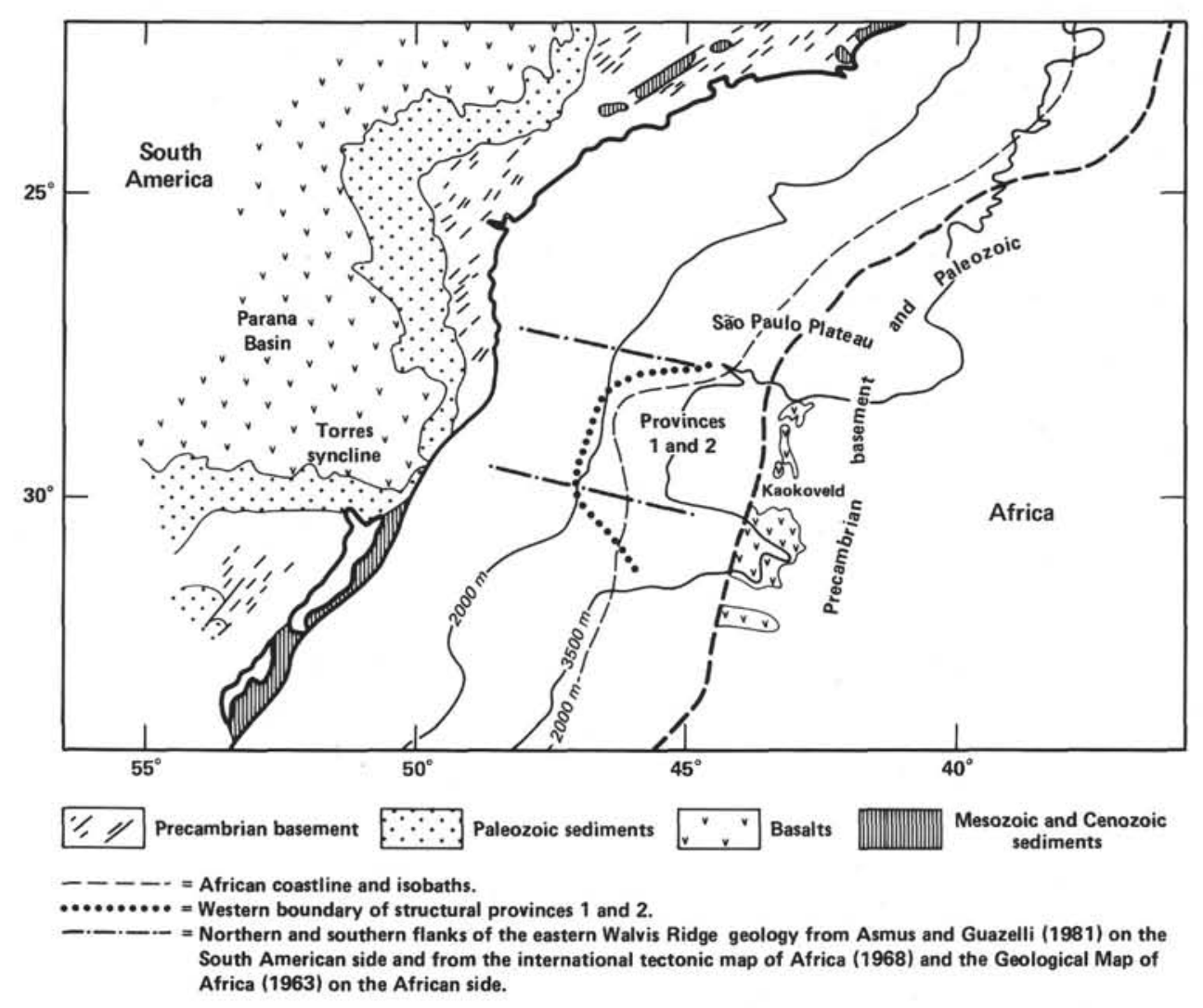

Figure 8. Initial reconstruction of the continents using the Bullard et al. (1965) fit in the area of the Parana Basin, Torres syncline, structural provinces 1 and 2 of the eastern Walvis Ridge, and Kaokoveld region. 
Plata at $35^{\circ} \mathrm{S}$ and the northern corner of Brazil at $5^{\circ} \mathrm{S}$. In the Late Jurassic to Early Cretaceous, the Paraná Basin and Torres syncline could have been the third rift arm of a R-R-R triple junction located at the intersection of the Torres syncline and the South American/African continental margins, as previously suggested by several authors (e.g., Herz, 1977; Neill, 1976; Asmus and Guazelli, 1981). In that case, the continental portion of the Walvis Ridge and the Kaokoveld basalts would lie on the same trend and would have had a common evolution.

\section{POSTRIFT SEQUENCE}

The postrift sequence after the appearance of oceanic crust differs from the earlier synrift sequence because the general morphology of the continental margins already had been acquired, and its subsequent history is related to general subsidence as a result of heat loss and contraction. The main tectonic episodes affecting the later history of the margin generally are related to changes in the plate motions (e.g., Sibuet and Mascle, 1978 ) or to local tectonic activity.

South of Walvis Ridge, the postrift sediments were deposited in the Walvis, Lüderitz, and Orange basins, followed by a general seaward progradation which continued into the Tertiary (Gerrard and Smith, 1983) (Fig. 4). North of Walvis Ridge, the postrift sequence corresponds to a relatively quiescent period with gentle regional subsidence. Local movements occurred along synrift faults, and halokinesis was still active during this period (Fig. 5). On Walvis Ridge, the faulted oceanward dipping internal basement-reflector sequence formed during the Early Cretaceous and the associated synrift sediments are covered by a largely terrigenous sedimentary sequence belonging to acoustic Unit 1 (Sibuet et al., this volume).

On the Brazilian side of the ocean, postrift sedimentation began with marine sediments of Albian-Cenomanian age deposited along the entire margin. The subsidence and flooding of the continental margin contrasted with uplift of the adjoining coastal area (Asmus and Guazelli, 1981). A renewal of both alkalic and basaltic activity occurred in the Aptian. The Minas Gerais-Goias belt of alkalic rocks, located northeast of the Paraná Basin, was emplaced from 91 m.y. until about 65 m.y. and the belt of alkalic rocks near Cabo Frio, started about 85 m.y. and lasted until about 59 m.y. (Herz, 1977). During the Cenozoic, a succession of events related to the initial formation of the Paraná Basin occurred, such as the uplift of the Ponta Grossa Arch.

\section{EARLY EVOLUTION OF THE SOUTH ATLANTIC OCEAN}

\section{Continent/Ocean Boundary on the African Side}

The positive magnetic anomaly associated with the Agulhas fracture zone was first interpreted by Talwani and Eldholm (1973) as a magnetic edge effect resulting from the juxtaposition of oceanic and continental basements. This hypothesis was supported by a two-dimensional computation assuming that the continental crust was less magnetized than the oceanic crust. An important isostatic gravity gradient coincides with the positive magnetic anomaly "G" (Talwani and Eldholm, 1973) and has been interpreted by Rabinowitz and $\mathrm{LaBrecque}$ (1979) as diagnostic of the COB. Rabinowitz and LaBrecque (1979) have extended this concept, applying it to the whole South Atlantic area, and proposed a new initial reassembly of Africa and South America differing considerably from that of Bullard et al. (1965) based on the fit of corresponding COB.

On the continental margin south of Walvis Ridge, Rabinowitz and LaBrecque (1979) have modelled magnetic Anomaly $\mathrm{G}$ as a magnetic edge effect linked to the oceanic-continental transition in a manner analogous to the magnetic anomalies previously modelled for the Agulhas margin. An associated free-air gravity anomaly high is observed but considerably reduced by the isostatic correction in the regions where Anomaly G is observed seaward of the shelf edge. In any case, the isostatic gravity anomaly is always associated with the magnetic Anomaly $\mathrm{G}$ even in the southern part of the margin where magnetic Anomaly G is not well developed (Rabinowitz and LaBrecque, 1979). As noted previously, Gerrard and Smith (1983) show that Anomaly G of Rabinowitz and LaBrecque (1979) is coincident with the eastern limit of the $T$ to $R$ synrift sequence (Fig. 3). Because the synrift sequence consists of basic lavas, Gerrard and Smith (1983) interpret both the gravity and magnetic anomalies as the result of density and susceptibility contrasts between the basic lavas and the adjacent sedimentary layers. For the continental margin south of Walvis Ridge, Anomaly G would be the edge of the normal continental crust rather than the COB. A distance of 150 to $220 \mathrm{~km}$ separates Anomaly G from the COB defined by Gerrard and Smith (1983) or Austin and Uchupi (1982). The validity of the initial fit for this region proposed by Rabinowitz and LaBrecque (1979) is open to question. However, this does not mean that equivalents of the Anomaly $\mathrm{G}$ may not be the $\mathrm{COB}$ on other continental margins.

At the latitude of the eastern Walvis Ridge, Sibuet et al. (this volume) propose that the COB is located at the limit between provinces 2 and 3 . The COB just north of Walvis Ridge is not clearly defined, because a ridge jump probably occurred in late Aptian-early Albian time (Sibuet et al., this volume). The oceanic crust west of Angola and Gabon is characterized by a flat surface and not by the usual irregular and chaotic topography. Consequently, the distinction between oceanic and continental character below the evaporitic sequence is difficult and a rather wide strip of crust of indeterminate type remains. In any case the COB must lie along or to the east of the western boundary of the evaporite sequence, which is marked by a magnetic anomaly.

\section{Age of the Beginning of the Rifting Period}

At DSDP Site 330 on the Falkland Plateau (Barker, Dalziel et al., 1976), geochemical and mineralogical results show that the first marine sediments are early Oxfordian (Maillot, 1982). A major unconformity exists at the base of the synrift sequence, and the best indica- 
tion of the beginning of the rifting period is given by dating the volcanic rocks. Alkalic and basaltic rocks in South Africa, Namibia, and southern Brazil associated with this tensional phase yield initial ages ranging between 136 and 147 m.y. (Siedner and Miller, 1968; Amaral et al., 1966; Cordani and Vandoros, 1967; Herz, 1977), i.e., Oxfordian-Kimmeridgian. Consequently an Oxfordian-Kimmeridgian age for the inception of the rifting period is in agreement with the available data.

\section{Age of the End of the Rifting Period}

The age of the end of the rifting period can be determined either by dating of the adjacent oceanic crust or by determining the end of the synrift phase. South of the Walvis Ridge, the more accurate method is the former. The oceanic anomalies abut against the COB (Fig. 3) defined by Gerrard and Smith (1983) and are younger towards the north. The ages of the intersection points are plotted as a function of latitude in Figure 9. Rabinowitz (1976) identified magnetic lineations east of the $\mathrm{COB}$ as defined by Gerrard and Smith and attributed them to an oceanic origin. These unquestionable magnetic lineations probably are associated with volcanics belonging to the synrift sequence and probably are located within the half grabens defined by the tilted fault block morphology trending roughly parallel to the continental margin (Sibuet et al., 1982).

North of Walvis Ridge, on the Cabinda continental margin, Brice et al. (in press) proposed that the synrift period ended at the beginning of Albian, after salt deposition (Fig. 9).

On the Brazilian continental margin, there is no direct indication of a northwards decrease in age of the end of the synrift sequence. Figure 9 shows that the length of the rifting period increases from about 20 m.y. at the latitude of the Agulhas Plateau to about 35 m.y. at the latitude of Gabon, which average to approximately the $30 \mathrm{~m}$.y. duration of the rifting phase suggested by Hay (1981). If we suppose that the amount of extension is about the same for all South Atlantic margins, this means that the early pole of rotation was located north of the Niger delta. The initial pole of rotation for an initial movement of South America with respect to Africa proposed by Sibuet and Mascle (1978), located in Senegal, is in agreement with this observation. Further, if we suppose that $160 \mathrm{~km}$ of extension is needed before the occurrence of oceanic crust, the extension rate would be $0.8 \mathrm{~cm} / \mathrm{yr}$. at the latitude of $\mathrm{Ga}$ bon. These rates are within the range of values generally accepted for the creation of continental margins.

\section{Age of Marine Incursions in the South Atlantic Ocean}

Marine Oxfordian sediments have been reported at DSDP Site 330 (Maillot, 1982), but the drilled synrift sequence in the A-C wells consists mainly of volcanics; there is no evidence of Late Jurassic marine sedimentation on the continental margin south of Walvis Ridge.

North of Walvis Ridge, on the Cabinda continental margin, the first hypersaline waters entered the basin from the south (Brice et al., 1983) and were initially

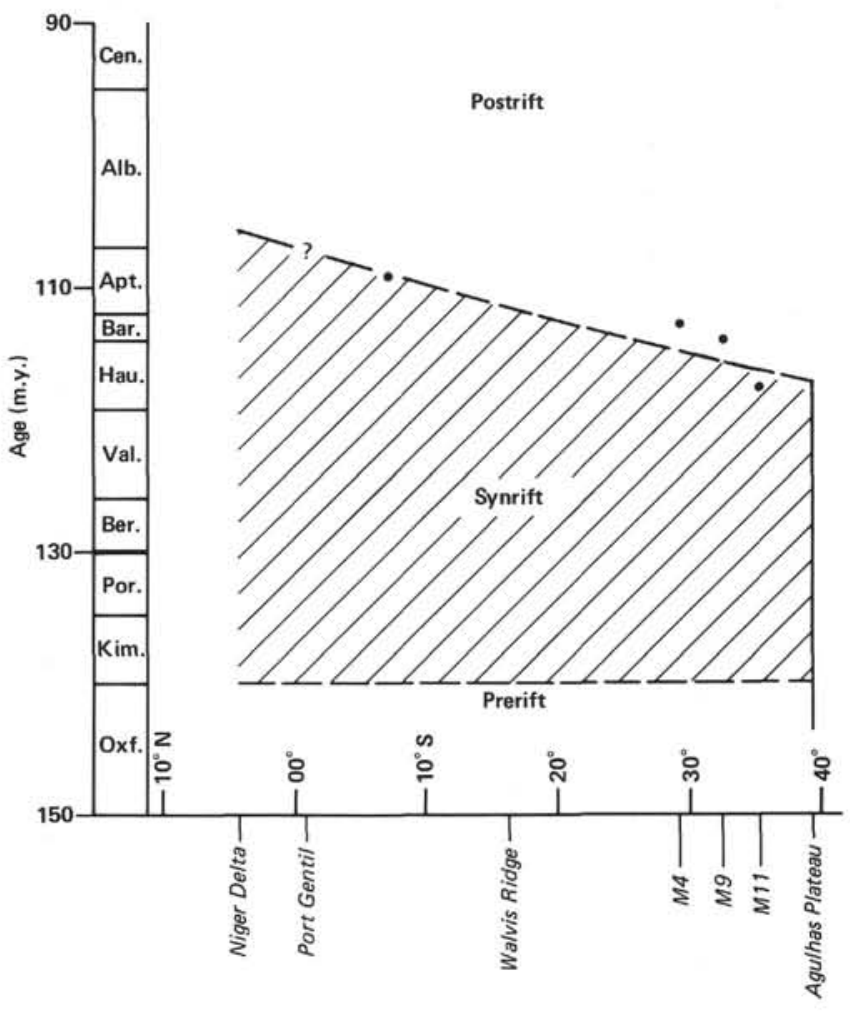

Figure 9. Duration of the synrift sequence along the African continental margin from Cape Agulhas to the Niger delta. Time scale from Odin (1982).

confined in subbasins before the thick evaporite sequence covered most of the area during the late Aptian. On the continental margin of Gabon, pre-evaporite sediments of mid-Aptian age may also have a marine origin (P. Valery, pers. comm.). Immediately north of Walvis Ridge there are no salt deposits on land, indicating that this part of the continent was above sea level at the time.

On the Brazilian margin, the first marine transgression is dated as Aptian by ammonites (Reyment, 1974) in the Reconcavo Basin. The role of Walvis Ridge as a dam to incursions of deep water from the south probably continued until mid-Aptian, corresponding to the end of the synrift sequence at the latitude of the Walvis Ridge (Fig. 9).

\section{Walvis Ridge-Rio Grande Rise: Key Features in the Early Paleoceanographic Evolution of the South Atlantic}

The initial fit of continents proposed in 1965 by Bullard et al. (Table 1) has been widely accepted for the South Atlantic. Sibuet and Mascle (1978), testing the Bullard et al. fit with more recent bathymetric data, did not find any significant difference (Table 1 ). However, the initial reconstruction proposed by Rabinowitz and LaBrecque (1979) diverges significantly from these two previous ones. The slight overlap of the Gabon and Brazil coastlines on the Rabinowitz and LaBrecque initial fit can probably be explained by the fact that the COB adopted by Rabinowitz and LaBrecque (1979) south of Walvis Ridge is in fact the eastern limit of synrift de- 
Table 1. Parameters of initial fit of the South Atlantic Ocean.

\begin{tabular}{ccc}
\hline \multicolumn{1}{c}{ Reference } & $\begin{array}{c}\text { Pole of } \\
\text { rotation }\end{array}$ & Angle \\
\hline $\begin{array}{c}\text { Bullard et al. (1965) } \\
(1,000 \text { fathoms) }\end{array}$ & $44.0^{\circ} \mathrm{N}, 30.6^{\circ} \mathrm{W}$ & $56^{\circ}$ \\
$\begin{array}{c}\text { Sibuet and Mascle (1978) } \\
(1,000 \text { fathoms) }\end{array}$ & $44.1^{\circ} \mathrm{N}, 30.3^{\circ} \mathrm{W}$ & $56.1^{\circ}$ \\
$\begin{array}{c}\text { Rabinowitz and LaBrecque } \\
(1979)(\mathrm{COB})\end{array}$ & $45.5^{\circ} \mathrm{N}, 32.2^{\circ} \mathrm{W}$ & $57.5^{\circ}$ \\
\hline
\end{tabular}

posits which corresponds to or is close to the eastern limit of the thinned continental crust. In that case, the magnetic lineations which had been identified as oceanic on the thinned continental crust west of South Africa, and which have no counterpart on the Argentine side (Rabinowitz and LaBrecque, 1979), may be associated, as previously proposed, with the volcanic infilling of the half grabens. These interpretations favor the Bullard et al. fit. We have consequently adopted the Bullard et al. fit as a first approximation for the initial reassembly of the Walvis Ridge-Rio Grande Rise and adjacent continents to serve as a basis for new discussion of the kinematic evolution of the South Atlantic Ocean (Sibuet et al., in prep.).

In this reconstruction (Fig. 8), the spur corresponding to structural provinces 1 and 2 of the eastern Walvis Ridge is located just south of the São Paulo Plateau. The bathymetric trend of the southern part of the São Paulo Plateau is parallel to the northern flank of the eastern Walvis Ridge (Fig. 8). In the Rabinowitz and LaBrecque reconstruction, this spur slightly overlaps the South American continent.

As proposed by Neill (1976) and demonstrated in previous sections, there is a strong similarity in nature and age of the Paraná Basin, the Torres syncline, structural provinces 1 and 2 of the eastern Walvis Ridge and the Kaokoveld region of Namibia. Basaltic and surrounding alkalic rocks of Late Jurassic-Early Cretaceous age could have been emplaced on a short-lived third arm of an R-R-R triple junction located on the South American side, with weaker activity on the African side in provinces 1 and 2 and in the Kaokoveld region. Thus, a two plate system in South America bounded at the latitude of the Torres syncline-Paraná Basin existed between 120 and 148 m.y. with maximum activity between 120 and 130 m.y. There is a gap of about $100 \mathrm{~km}$ between Agulhas and Falkland fracture zones in the initial reconstructions (e.g., in the Bullard et al. fit, as shown in fig. 14 of Rabinowitz and LaBrecque, 1979) suggesting that roughly north-south extension of about this amount occurred in the Torres syncline-Paraná Basin rift arm. This is supported by the fact that the western $400 \mathrm{~km}$ of the Falkland Fracture Zone trends W-NW rather than E-W as does the rest of the Falkland Fracture Zone or as does the whole rotated Agulhas Fracture Zone. One can thus model the early evolution of the South Atlantic Ocean starting with these initial conditions (Sibuet et al., in prep.).

\section{CONCLUSIONS}

This study has yielded the following conclusions concerning the early evolution of the South Atlantic Ocean:

1) The beginning of the rifting period is OxfordianKimmeridgian (136-147 m.y.).

2) The end of the rifting period and the subsequent appearance of oceanic crust varies over an interval of about 15 m.y. from Hauterivian (M11) near the Agulhas Plateau to early Albian in the vicinity of the Niger Delta.

3) The Paraná Basin, the Torres syncline, structural provinces 1 and 2 of the eastern Walvis Ridge and the Kaokoveld region of Namibia form a volcanic feature that was originally continuous and was created in a continental domain between 110 and 148 m.y. with maximum volcanic activity occurring between 120 and 130 m.y. (Berriasian-Valanginian).

4) This volcanic feature probably corresponds to an extinct rift arm on the South American plate as a consequence of about $100 \mathrm{~km}$ of north-south extension in the Late Jurassic to Early Cretaceous.

5) These factors provide major constraints for the early kinematic evolution of the South Atlantic (Sibuet et al., in prep.).

\section{ACKNOWLEDGMENTS}

The authors especially acknowledge the Centre National pour l'Exploitation des Océans, the Institut Français du Pétrole, the Comité d'Etudes Pétrolières Marines and the Bundesanstalt für Geowissenschaften und Rohstoffe for their financial support and encouragement of scientific cruises in the South Atlantic Ocean. We are especially grateful to I. Gerrard and S. E. Brice for making available preprints of their works before publication. We greatfully acknowledge the efforts of Walter Dean and Eric Barron, who critically reviewed and improved the manuscript and offered helpful suggestions. We thank Daniel Carré for preparing the illustrations. This is contribution 827 of the Centre Océanologique de Bretagne.

\section{REFERENCES}

Almeida, F. F. M., 1972. Tectono-magmatic activation of the South American platform and associated mineralization. 24th Int. Geol. Congr., 3:339-346.

Amaral, G., Cordani, U. G., Kawashita, K., and Reynolds, J. H, 1966. Potassium argon dates of basaltic rocks from southern Brazil. Geochim. Cosmochim. Acta, 30:159-189.

Asmus, H. E., and Guazelli, W., 1981. Descriao sumaria das estruturas da margem continental brasileira e das areas oceanicas et continentals, adjacentes-Hypotheses sobre o tectonismo causador, e implicacoes para os prognosticos do potential de recursos minerais. In Asmus, H. E. (Ed)., Estruturas e Tectonismo da Margem Continental Brasileira, e Suas Implicacoes Nos Processos Sedimentares e na Availacao do Potencial de Recursos Minerais: Projeto Remac, Petrobras, Rio de Janeiro, Brazil, 9:187-269.

Asmus, H. E., and Ponte, F. C., 1973. The Brazilian marginal basins. In Nairn, A. E. M., and Stehli, F. G (Eds.), The Ocean Basins and Margins, The South Atlantic (Vol. 1): New York (Plenum Press), 87-133.

Austin, J. A., and Uchupi, E., 1982. Continental-oceanic crustal transition off southwest Africa. Am. Assoc. Pet. Geol. Bull., 66:1328-1347.

Barker, P., Dalziel, I.W.D., et al., 1976. Init. Repts. DSDP, 36: Washington (U.S. Govt. Printing Office).

Barnaby, A. M., 1974. The structure of the eastern Walvis Ridge and the adjacent continental margins [Unpubl. M. Sc. Dissert.]. University of Capetown, South Africa. 
Bolli, H. M., Ryan, W. B. F., Foresman, J. B., Hottman, W. E., Kagami, H., Longoria, J. F., Mcknight, B. K., Melguen, M., Natland, J., Proto-Decima, F., and Siesser, W. G., 1978. Walvis Ridge-Sites 362 and 363. In Bolli, H. M., Ryan, W. B. F., et al., Init. Repts. DSDP, 40: Washington (U.S. Govt. Printing Office), 183-356.

Brice, S. E., Cochran, M. D., Pardo, G., and Edwards, E. D., 1983. Tectonics and sedimentation of the South Atlantic rift sequence: Cabinda, Angola. In Watkins, J. S., and Drake, C. L. (Eds.), Studies in Continental Margin Geology. Am. Assoc. Pet. Geol. Mem., 34:5-20.

Bullard, E. C., Everett, J. E., and Smith, A. G., 1965. The fit of the continents around the Atlantic. In Blackett, P. M. S., Bullard, E. C., and Runcorn, S. K. (Eds.), A Symposium on Continental Drift. Philos. Trans. R. Soc. London, 258A:41-51.

Cordani, U. G., and Vandoros, P., 1967. Basaltic rocks of the Parana Basin. Problems in Brazilian Gondwana Geology: Curitiba, Brazil (Conselho Nacional de Pesquisas, Univ. Federal, Inst. Geol.), pp. 207-231.

Dalziel, I. W. D., and Elliot, D. H., 1972. The Scotia arc and Antarctic margin. In Nairn, A. E. M., and Stehli, F. G. (Eds.), The Ocean Basins and Margins: The South Atlantic, (Vol. 1): New York (Plenum Press), 171-246.

Damasceno, E. C., 1966. Estudo preliminar dos diques de rochas basicas e ultrabasicas da regiao de Ubztuba, Estado de São Paulo. Anais Acad. Brasileira de Ciencas, 38:293-304.

Davis, E. E., 1982. Evidence for extensive basalt flows on the sea floor. Geol. Soc. Am. Bull., 93:1023-1029.

de Graciansky, P. C., Poag, C. W., et al., in press. Init. Repts. DSDP, 80: Washington (U.S. Govt. Printing Office).

Detrick, R., and Watts, A. B., 1979. An analysis of isostasy in the world's oceans: 3, Aseismic ridges. J. Geophys. Res., 84:3637-3653.

Emery, K. O., Phillips, J., Bowin, C., and Mascle, J., 1975a. Continental margin off western Africa: Angola to Sierra Leone. Am. Assoc. Pet. Geol. Bull., 59:2209-2265.

Emery, K. O., Uchupi, E., Bowin, C., Phillips, J., and Simpson, E. S. W., 1975b. Continental margin off western Africa: Cape St-Francis (South Africa) to Walvis Ridge (South West Africa). Am. Assoc. Pet. Geol. Bull., 59:3-59.

Foucher, J.-P., LePichon, X., and Sibuet, J.-C., 1982. The ocean-continent transition in the uniform lithospheric stretching model: Role of partial melting in the mantle. Philos. Trans. R. Soc. London, 305A:27-43.

Francheteau, J., and LePichon, X., 1972. Marginal fracture zone as structural framework of continental margins in the South Atlantic Ocean. Am. Assoc. Pet. Geol. Bull., 56:991-1007.

Geological Map of Africa, 1963. Association of African Geological Surveys and United Nations Educational Scientific and Cultural Organization.

Gerrard, I., and Smith, G. C., 1983. In Watkins, J. S., and Drake, C. L. (Eds.), Studies in Continental Margin Geology. Am. Assoc. Pet. Geol. Mem., 34:49-76. The post Paleozoic succession and structure of the South-Western African continental margin. Proc. Hedberg Conf., Galveston, Texas, January 1981.

Goslin, J., Mascle, J., Sibuet, J.-C., and Hoskins, H., 1974. Geophysical study of the easternmost Walvis Ridge, South Atlantic: Morphology and shallow structure. Geol. Soc. Am. Bull., 85:619-632.

Goslin, J., and Sibuet, J.-C., 1975. Geophysical study of the easternmost Walvis Ridge, South Atlantic: Deep structure. Geol. Soc. Am. Bull., 86:1713-1724.

Guazelli, W., and de Carvalho, J. C., 1981. Estruturas da margem continental del este brasileira e das areas oceanicas e continentais, adjacentes. In Asmus, H. E. (Ed.), Estructuras e Tectonismo da Margem Continental Brasileira, e Suas Implicacoes Nos Processos Sedimentares e na Avaliacao de Potencial de Recursos Minerais: Rio de Janeiro, Brazil, Projecto Remac, Petrobras, 9:187-269.

Hay, W. W., 1981. Sedimentological and geochemical trends resulting from the breakup of Pangaea. Oceanol. Acta, 4(Suppl.):135-147.

Hay, W. W., Behensky, J. F., Jr., Barron, E. J., and Sloan, J. L., II, 1982. Late Triassic-Liassic paleoclimatology of the proto-central North Atlantic Rift system. Palaeogeogr. Palaeoclimatol., $\mathrm{Pa}$ laeoecol., 40:13-30.

Hay, W. W., Sibuet, J.-C., Barron, E., Boyce, R. E., Brassell, S., Dean, W. E., Huc, A. Y., Keating, B. H., McNulty, C. L., Meyers, P. A., Nohara, M., Schallreuter, R. E., Steinmetz, J. C., Stow, D., and Stradner, H., 1982. Sedimentation and accumulation of organic carbon in the Angola Basin and on Walvis Ridge: Preliminary results of Deep Sea Drilling Project Leg 75. Geol. Soc. Am. Bull., 93:1038-1050.

Herz, N., 1977. Timing of spreading in the South Atlantic: Information from Brazilian alkalic rocks. Geol. Soc. Am. Bull., 88: 101-112.

Hinz, K., 1981. A hypothesis on terrestrial catastrophes: Wedges of very thick oceanward dipping layers beneath passive continental margins-Their origin and paleoenvironmental significance. Geol. Jb., 22:3-28.

International Tectonic Map of Africa, 1968. Association of African Geological Surveys and United Nations Educational Scientific and Cultural Organization.

Kogan, M. G., 1979. Gravity anomalies and origin of the Walvis Ridge. J. Geophys. Res., 84:6019-6025.

Ladd, J. W., Dickson, G. O., and Pitman, W. C., III, 1973. The age of the South Atlantic. In Nairn, A. E. M., and Stehli, F. G. (Eds.), The Ocean Basins and Margins, The South Atlantic (Vol. 1): New York (Plenum).

Lehner, P., and De Ruiter, P. A. C., 1977. Structural history of Atlantic margin of Africa. Am. Assoc. Pet. Geol. Bull., 61:961-981.

LePichon, X., Melguen, M., and Sibuet, J.-C., 1978. A schematic model of the evolution of the South Atlantic. In Charnock, H., and Deacon, G. (Eds.), Advances in Oceanography: New York (Plenum Press), pp. 1-48.

LePichon, X., and Sibuet, J.-C., 1981. Passive margins: A model of formation. J. Geophys. Res., 86:3708-3720.

Leyden, R., Bryan, G., and Ewing, M., 1972. Geophysical reconnaissance on African shelf: 2. Margin sediments from Gulf of Guinea to Walvis Ridge. Am. Assoc. Pet. Geol. Bull., 56:682-693.

Leyden, R., Ludwig, W. J., and Ewing, M., 1971. Structure of continental margin off Punta del Este and Rio de Janeiro, Brazil. Am. Assoc. Pet. Geol. Bull., 55:2161-2173.

Maillot, H., 1982. Les paléoenvironnements de l'Atlantique Sud: Apport de la géochimie sédimentaire [Thèse]. Université des Sciences et Techniques de Lille, France.

Martin, H., 1973. The Atlantic margin between latitude $17^{\circ}$ south and Cape of Good Hope. In Nairn, A. E. M., and Stehli, F. G. (Eds.), The Ocean Basins and Margins, The South Atlantic (Vol. 1): New York, (Plenum Press), 377-300.

Matthews, D. J., 1939. Tables of the Velocity of Sound in Pure Water and Sea Water for use in Echo sounding and Sound Ranging: Admiralty, London (Hydrographic Department).

Montadert, L., de Charpal, O., Roberts, D. G., Guennoc, P., and Sibuet, J.-C., 1979a. Northeast Atlantic passive margins: Rifting and subsidence processes. In Talwani, M., Hay, W. W., and Ryan, W. B. F. (Eds.), Deep Drilling Results in the Atlantic Ocean: Continental Margins and Paleoenvironment: Washington (Am. Geophys, Union), Maurice Ewing Series, 3:164-186.

Montadert, L., Roberts, D. G., et al., 1979b. Init. Repts. DSDP, 48: Washington (U.S. Govt. Printing Office).

Mutter, J. C., Talwani, M., and Stoffa, P. L., 1982. Origin of seawarddipping reflectors in oceanic crust off the Norwegian margin by subaerial sea-floor spreading. Geology, 40:353-357.

Neill, W. M., 1976. Mesozoic epeirogeny at the South Atlantic margin and the Tristan hot spot. Geology, 4:495-498.

Odin, G. S., 1982. Numerical Dating in Stratigraphy: Chichester, England (Wiley.).

Rabinowitz, P. D., 1972. Gravity anomalies on the continental margin of Angola, Africa. J. Geophys. Res., 77:6327-6347.

Rabinowitz, P. D., 1976. A geophysical study of the continental margin of southern Africa. Geol. Soc. Am. Bull., 87:1643-1653.

Rabinowitz, P. D., and LaBrecque, J., 1979. The Mesozoic South Atlantic Ocean and evolution of its continental margins. J. Geophys. Res. 84:5973-6002.

Reyment, R. A., 1974. Application des méthodes paléobiologiques à la théorie de la dérive des continents, illustrée par l'Atlantique Sud. Rev. Géogr. Phys. Géol. Dynamique, 16:61-70.

Roberts, D. G., Schnitker, D., Backman, J., Baldauf, J. G., Desprairies, A., Homringhausen, R., Huddlestun, P., Kaltenback, A. J., Keene, J. B., Krumsiek, K. A. O., Morton, A. C., Murray, J. W., Westberg-Smith, J., and Zimmermann, H. B., 1982. North Atlantic Leg 81 drills west margin Rockall Plateau. Geotimes, 9:21-23. 
Royden, L., Sclater, J. G., and Von Herzen, R. P., 1980. Continental margin subsidence and heat flow: Important parameters in formation of petroleum hydrocarbons. Am. Assoc. Pet. Geol. Bull., 64:137-187.

Sartori, P. L., Maciel Filho, C., and Menegott, E., 1975. Contribution to the study of Parana Basin volcanic rocks in the region of Santa Maria, State of Rio Grande do Sul. Rev. Bras. Geociencas, 5:141-159.

Scrutton, R. A., 1976. Crustal structure of the continental margin south of South Africa. Geophys. J., 44:601-624.

Sibuet, J.-C., Amortila, P., Foucher, J.-P., and LePichon, X., 1982. Tilted fault blocks on the continental margin west of the Iberian peninsula: A test of the stretching model. EOS, 63:1276.

Sibuet, J.-C., and Mascle, J., 1978. Plate kinematic implications of Atlantic equatorial fracture zone trends. J. Geophys. Res., 83: 3401-3421.

Siedner, G., and Miller, J. A., 1968. K-Ar age determinations on basaltic rocks from southwest Africa and their bearing on continental drift. Earth Planet. Sci. Lett., 4:451-458.

Simpson, E. S. W., 1971. The geology of the southwest African continental margin: A review. The Geology of the East Atlantic Conti- nental Margin, 2, Africa: Cambridge, England (ICSU/SCOR working party 31 Symposium, Rep. 70-/16, Int. Counc. Sci. Unions).

Talwani, M., and Eldholm, O., 1973. The boundary between continental and oceanic basement at the margin of rifted continents. Nature, 241:235-330.

van Andel, Tj. H., Thiede, J., Sclater, J. G., and Hay, W. W., 1977. Depositional history of the South Atlantic Ocean during the last 125 my. J. Geol., 85:651-698.

Vogt, P. R., and Einwich, A. M., 1979. Magnetic anomalies and seafloor spreading in the western North Atlantic, and a revised calibration of the Keatley (M) geomagnetic reversal chronology. In Tucholke, B. E., Vogt, P. R., et al., Init. Repts. DSDP, 43: Washington (U.S. Govt. Printing Office), 857-876.

Zambrano, J. J., and Urien, C. M., 1970. Geological outline of the basins in southern Argentina and their continuation off the Atlantic. J. Geophys. Res., 75:1363-1369.

Date of Initial Receipt: June 20, 1983 